\title{
New extension range and complementary description of Eurytemora americana (Calanoida: Temoridae) in northern Korea
}

\author{
Seong Yong Moon ${ }^{1 *}$, Jung-Hwa Choi ${ }^{1}$, Jung-Nyun $\mathrm{Kim}^{2}$, Sun-Kil Kim and Balu Alagar Venmathi Maran ${ }^{3}$
}

\begin{abstract}
Background: The brackish calanoid, Eurytemora americana Williams, 1906, is reported in the northern part of Korea. It is found to be an important copepod in the mesozooplankton community structure from the estuarine and shallow waters. The range extension and of E. americana is reported additionally to previously known distributional range from brackish waters of the South Atlantic Ocean, United Kingdom, Canada, English Channel, Iceland, the North Atlantic Ocean, the North Pacific Ocean (Japan, Korea, and Russia), and the North Sea. In this study, both sexes of E. americana are redescribed and illustrated including their undescribed mouthparts.

Results: The most important characters that have been overlooked in the previous descriptions are: shape of the last pedigerous somite in female, structure of the genital double-somite, and ornamentation of the fifth leg in both sexes.

Conclusion: The distributional range of E. americana is now given with its northern and southern hemisphere limit as 70 to $37^{\circ} \mathrm{N}$ in the North Pacific and $38^{\circ} \mathrm{S}$ in the Southwest Atlantic.
\end{abstract}

Keywords: Copepod, Eurytemora americana, Distribution, Taxonomy, Northern Korea

\section{Background}

Most of the species belonging to the family Eurytemora Giesbrecht, 1881 are distributed in both, northern and southern hemispheres and about 30 species have so far been described (Boxshall and Halsey 2004; Alekseev and Souissi 2011; Sukhikh and Alekseev 2013). The genus has hitherto been recorded exclusively from subtropical to subarctic, but with the increasing species diversity toward northern latitudes (Dodson et al. 2010). Most of the Eurytemora are characterized by a wide habitat distribution ranging from the open ocean waters, coastal marine, hypersaline salt marshes, and brackish estuaries, to completely freshwaters (Heron and Damkaer 1976; Lee 2000; Dodson et al. 2010).

Two of Eurytemora species E. composita Keiser, 1929 and E. pacifica Sato, 1913 have so far been recorded

\footnotetext{
* Correspondence: msy7744@korea.kr

${ }^{1}$ Southeast Sea Fisheries Research Institute, National Institute of Fisheries

Science, Tongyoung 53085, Korea

Full list of author information is available at the end of the article
}

from Korea (Lee et al. 2007; Soh et al. 2013) and E. pacifica has known to be a dominant species in estuarine to shallow waters of Korea (Park et al. 2002; Moon et al. 2006, 2012).

We have conducted the faunistic studies on the calanoids in eastern estuarine and shallow waters of Korea from May to June 2011. In the materials collected of the studied area, the predominant species was E. americana Williams, 1906, it co-occurred with E. pacifica Sato, 1913. In the current re-examination of the obtained materials, we have found that E. americana was erroneously identified as E. pacifica, while E. pacifica was actually rare in these waters. The complete redescription of E. americana from the eastern Korea estuarine and shallow waters is presented herein to clarify the identification of the northern Korean calanoid reported as $E$. pacifica to avoid possible misunderstanding of the identity of the species.

\section{Materials and methods}

The specimens were collected from the estuarine and coastal waters of eastern Korea (Table 1, Fig. 1) using a 
Table 1 Distribution of three different species of Eurytemora (Temoridae) in Korean waters

\begin{tabular}{|c|c|c|c|c|}
\hline Species & $\begin{array}{l}\text { Occurrence } \\
\text { locality } \\
\text { (see Fig. 1) }\end{array}$ & Gear & $\begin{array}{l}\text { Mesh size } \\
(\mu \mathrm{m})\end{array}$ & References \\
\hline E. pacifica & $\begin{array}{l}1-12,14 \\
15,16,20\end{array}$ & $\begin{array}{l}\text { Plankton net, } \\
\text { Norpac net }\end{array}$ & $\begin{array}{l}64,100 \\
200\end{array}$ & $\begin{array}{l}\text { Lee et al. (2007), Soh } \\
\text { (2010), Present study }\end{array}$ \\
\hline $\begin{array}{l}E . \\
\text { americana }\end{array}$ & $\begin{array}{l}15,16,18 \\
22\end{array}$ & Norpac net & 100 & Present study \\
\hline $\begin{array}{l}\text { E. } \\
\text { composita }\end{array}$ & $\begin{array}{l}13,17,19, \\
21\end{array}$ & $\begin{array}{l}\text { Plankton net, } \\
\text { Norpac net }\end{array}$ & 64,100 & $\begin{array}{l}\text { Lee et al. (2007) } \\
\text { Soh et al. (2013) }\end{array}$ \\
\hline
\end{tabular}

plankton net (100 and $200 \mu \mathrm{m}$ mesh). The samples were preserved immediately in $5 \%$ buffered formalin/seawater solution. Individuals of the species were sorted out from the samples. Before dissection and microscopic observation, specimen was immersed in $70 \%$ lactic acid for about an hour. Dissection of specimen was done using reverse slide method (Humes and Gooding 1964). The descriptive terminology follows Huys and Boxshall
(1991). Abbreviations used in the text and figures: A1, antennule; ae, aesthetasc. All voucher specimens are deposited at the National Institute of Biological Resources (NIBR), Incheon, Korea.

\section{Results \\ Systematics}

Order CALANOIDA G. O. Sars, 1903

Family TEMORIDAE G. O. Sars, 1903

Genus Eurytemora Giesbrecht, 1881

Eurytemora americana Williams, 1906

Figs. 2-5

\section{Synonymy}

Eurytemora americana Williams, 1906: 645, figs. 8-11; Wilson C. B., 1932: 109, fig. 72; Gurney 1933: 369, figs. 2048-2061; Jespersen, 1940: 42, fig. 6; Brodsky 1950: 284, fig. 193; Fontaine, 1955: 858, pls. 8, figs. 1-15;

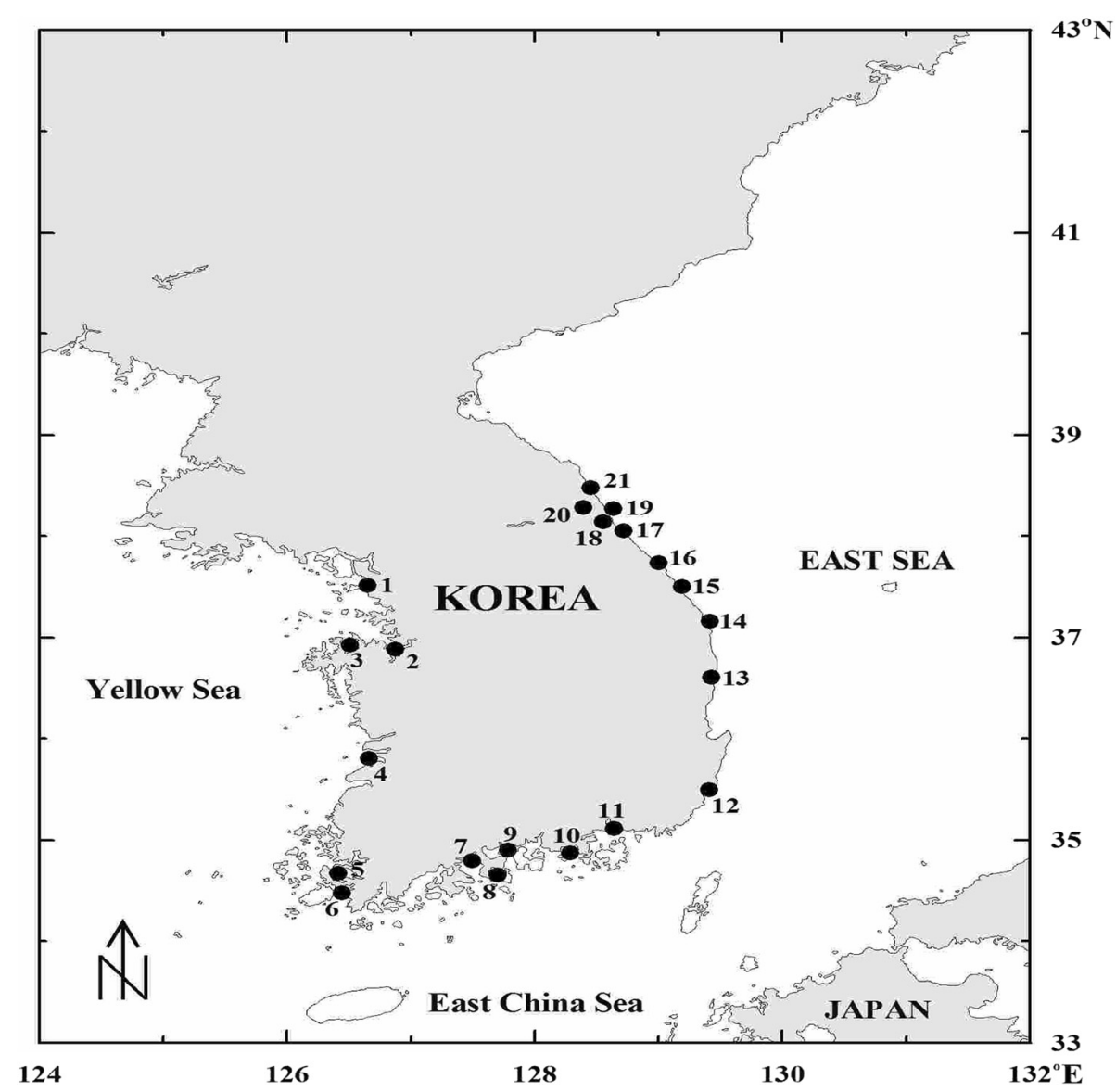

Fig. 1 Sampling stations in different parts of Korea:(1) Incheon Port; (2) Asan Bay; (3) Garolim Bay; (4) Mankyung River estuary; (5) Mokpo Port; (6) Jindo Port; (7) Yeoja Bay; (8) Gamak Bay; (9) Seomjin River estuary; (10) Sacheon Port; (11) Jinhae Bay; (12) Ulsan Bay; (13) Ganggu (Goraebul stream); (14) Samcheok Port; (15) Jincheon stream, Donghae; (16) Gangneung Port; (17) Yangyang Port; (18) Sokcho Port; (19) Songjiho lake; (20) Gwangpoho Lake; (21) Goseong Port 
Smith, 1960: 13, fig. 5; Heron 1964: 206, figs. 19-26; Jerusalem 1967: 287; Kos 1977: 33, figs. 11-13;

Borutzky et al. 1991: 116; Brylinski 2009: 254, fig. 2.

Eurytemora thompsoni: Willey 1923: 303, fig. 7;

Lowndes 1931: 501, figs. 1-16; Brodsky 1950: 287,

fig. 195.

Eurytemora transversalis: Campbell 1930: 179, pl. 1, figs. 4-6; Brodsky 1950: 288, fig. 197.

Eurytemora kieferi: Smirnov 1931: 194, figs. 1-6;

Brodsky 1950: 287, fig. 196.

\section{Material examined}

$21 ㅇ ㅗ$ and $24 \delta^{\lambda} \delta^{\lambda}$, Jeoncheon stream $\left(37^{\circ} 39^{\prime} 26^{\prime \prime} \mathrm{N}, 129^{\circ}\right.$

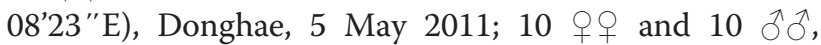
Sacheon port, Gangneung, 19 June 2010; 12 우 and 3

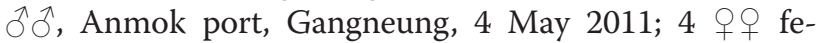
males and $2 \widehat{\delta}$, Cheongok port, Donghae, 5 May 2011; $25 ㅇ ㅗ$ and $14 \hat{\partial} \hat{\partial}$, Geojin port, Goseong, 7 May 2011; 1 q, Jangho port, Samcheok, 12 May 2011; 5 우 and 3

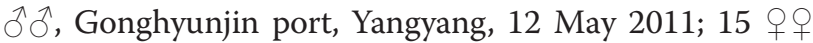
and $11 \hat{\jmath} \widehat{\partial}$, Bongpo port, Goseong, 1 June 2011.

\section{Description}

\section{Female}

Body plump (Fig. 2a, b), length 1.17-1.25 mm (mean $1.21 \pm 0.09, n=10$ ). Rostral filaments thick and short (Fig. 4f). Prosome-urosome ratio 1.51:1. Cephalosome and first pedigerous somite completely separated; fourth and fifth pedigerous somites completely separated; last pedigerous somite slightly asymmetrical with 1 small spinule on wing-like protrusion terminally on both sides. Urosome of 3 free somites: genital double-somite symmetrical, lateral margins slightly constricted at midlength; both proximal and distal sides prominent (Fig. 2d), 1.31 times as long as wide; genitial operculum (Fig. 2e, indicated by black arrow) located ventromedially with long rounded overlying area of receptacle. Third urosomal segment with spinules dorsolaterally (Fig. 2f). Caudal rami nearly symmetrical (Fig. 2f), 6.9 times longer than wide, with spinules dorsolaterally, and 6 caudal setae, seta I lacking.

Antennule: 24-segmented, reaching to distal part of last pedigerous somite (Fig. 2b): ancestral segments III, III-IV, and XXVI-XXVIII completely fused (Fig. 2c). Segmentation and setation patterns as follows (ancestral segment number-setae $+\mathrm{ae})$ : I-II-3 + ae, III-IV$3+$ ae, V-2 + as, VI-1, VII-2 + ae, VIII-1, IX-2 + ae, $\mathrm{X}-1, \mathrm{XI}-2$ + ae, XII-1, XIII-1, XIV-2 + ae, XV-2, XVI-2 + ae, XVII-2, XVIII-2 + ae, XIX-2, XX-2, XXI-1 + ae, XXII-1, XXIII-1, XXIV-1 + 1, XXV$1+1$, XXVI-XXVIII-6 + ae.

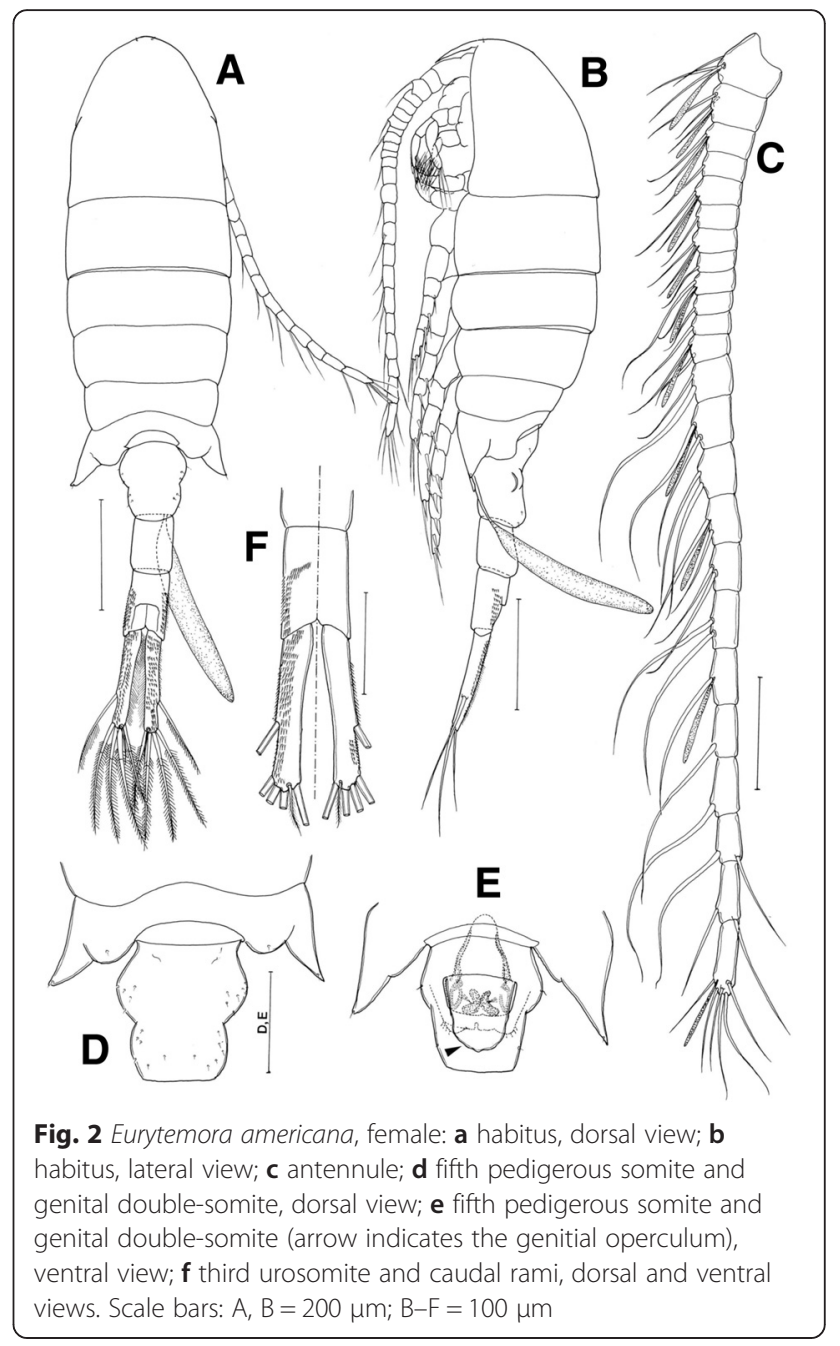

Antenna (Fig. 3a): Coxa and basis with 1 and 2 setae, respectively; endopod 2-segmented, proximal segment with 2 setae, distal segment with 9 setae subterminally, 7 setae terminally; exopod 7 -segmented, with seta formula of 1, 3, 1, 1, 1, 1, $1+3$.

Mandible (Fig. 3b): gnathobase well developed, cutting edge with short teeth and dorsal seta; basis of palp with 4 setae; exopod 5-segmented, with setal formula of $1,1,1,1,2$; endopod 2-segmented, proximal and distal segment with 4 and 10 setae, respectively. Maxillule (Fig. 3c): praecoxa and coxa incompletely fused; praecoxal arthrite with 14 setae (9 spines and 5 setae), row of spinules on posterior surface; coxa with 4 setae on coxalendite and 9 setae on epipodite; basis with 3 and 5 setae on basal endites, basal exite with 1 seta; endopod incompletely 3-segmented, with setal formula of 5, 5, 6; exopod with 9 setae, row of spinules on posterior surface.

Maxilla (Fig. 3d): praecoxa and coxa incompletely fused, proximal praecoxal endite with 5 setae, distal and coxal endites with 3 setae each; basis with 4 


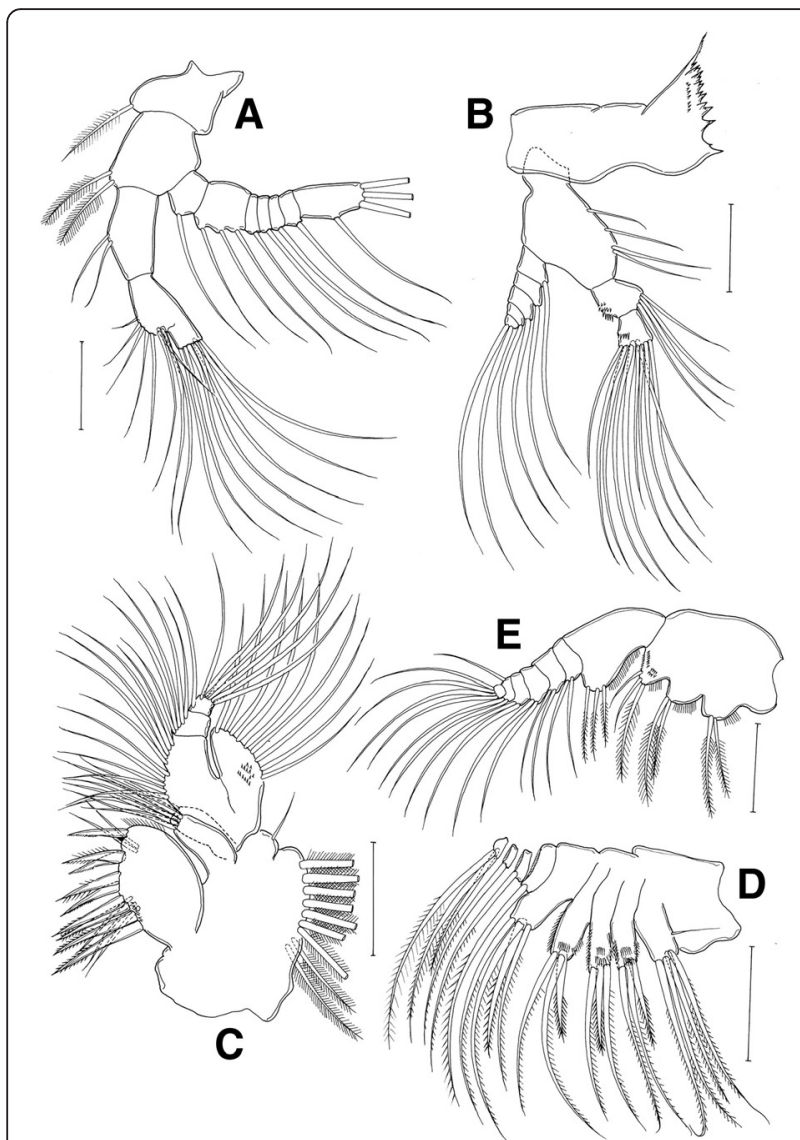

Fig. 3 Eurytemora americana, female: a antenna; b mandible; c maxillule; $\mathbf{d}$ maxilla; e maxilliped. All scales $=50 \mu \mathrm{m}$

setae; endpod 4-segmented, with setal formula of $1,1,1,3$.

Maxilliped (Fig. 3e): syncoxa robust, with setal formula of 2, 2, 3 and oblique rows of tiny spinules on posterior surface; basis with 3 setae and row of spinules on medial surface endopod 6-segmented, with setal formula of 2, 2, 2, 2, 2+1, 4 .

Legs 1 to 4 (Table 2, Fig. 4a-d) with 3-segmented exopods, 2-segmented endopods, except for endopod 1 -segmented in leg 1. Coxa of leg 1 (Fig. 4a), with tiny spinules on posterior surface.

Fifth leg (Fig. 4e) 4-segmented; coxa with seta on ventral surface; basis/exopod segment 1 with strong comb-like inner process, directed inwards, tip upcurved and finely serrate along both margins of distal half, and 2 setae (1 proximal and 1 distal margin); exopod segment 2 with 2 distal setae.

Male

Body more slender than in female (Fig. 5a, b), length $1.17-1.25 \mathrm{~mm}$ (mean $1.21 \pm 0.09, n=10$ ). Prosomeurosome ratio 1.52:1. Cephalosome bearing dorsal hump, (indicated by the black arrow in Fig. 5b) and completely separated from first pedigerous somite;

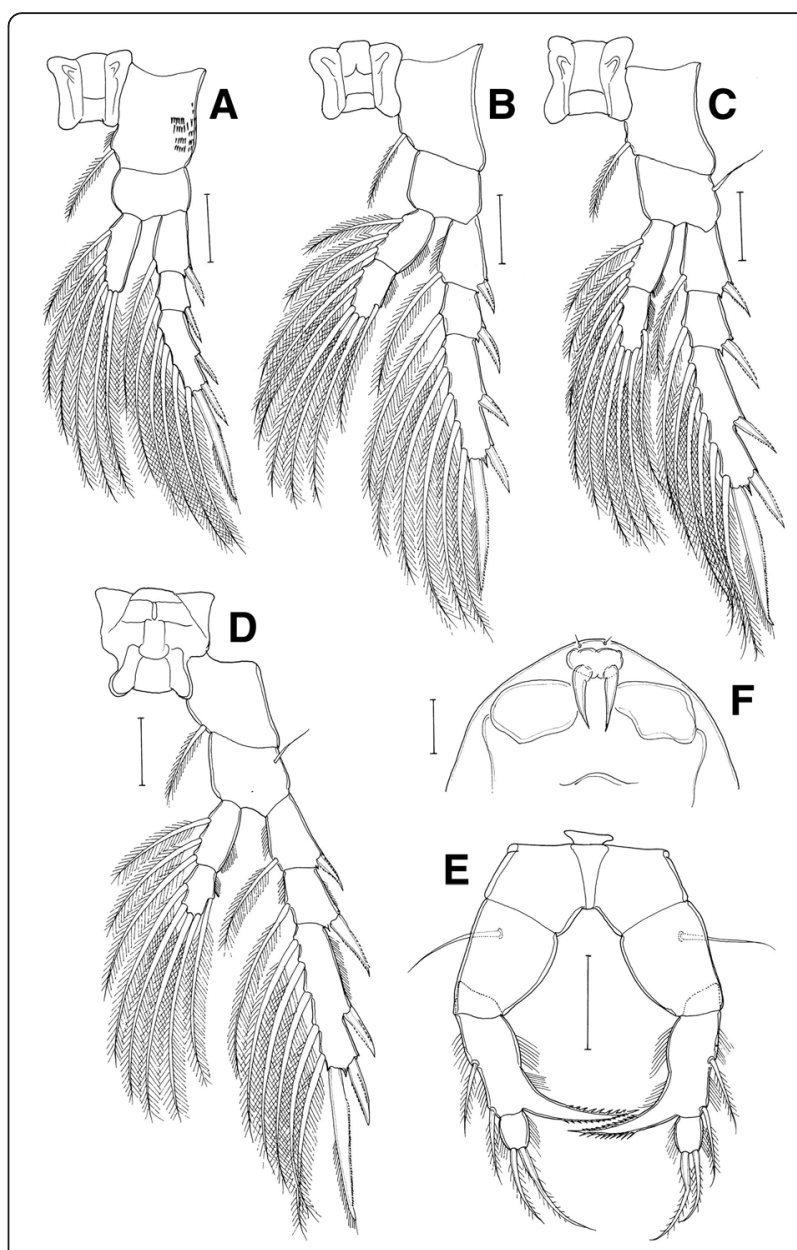

Fig. 4 Eurytemora americana, female: a leg 1, anterior view; b leg 2, anterior view; c leg 3, anterior view; d leg 4 anterior view; e leg 5, anteior view; $\mathbf{f}$ rostral filaments. All scale bars $=50 \mu \mathrm{m}$

fourth and fifth pedigerous somites completely separated; posterior corners of prosome rounded. Urosome of 5 free somites, proximal segment asymmetrical, second urosomal somite longest (Fig. 5a, e). Caudal rami nearly symmetrical, approximately 6.42 times longer than wide, and with 6 caudal setae, setae I lacking.

Antennule: 20-segmented, extending to distal part of third usosomite (Fig. 5a, c): ancestral segment I-II, III-IV, XXI-XXIII and XXIV-XXVIII completely fused. Segmentation and setation patterns as follows:

Table 2 Spine and setal formula of swimming legs 1 to 4 of Eurytemora americana collected from Korea

\begin{tabular}{lllll}
\hline & Coxa & Basis & Exopod & Endopod \\
\hline Leg 1 & $0-1$ & $0-0$ & $|-1 ;|-1 ; \mid I, I, 4$ & $0,2,4$ \\
Leg 2 & $0-1$ & $0-0$ & $|-1 ;|-1 ; \mid I, I, 5$ & $0-3 ; 1,2,3$ \\
Leg 3 & $0-1$ & $0-1$ & $|-1 ;|-1 ; \mid I, I, 5$ & $0-3 ; 1,2,3$ \\
Leg 4 & $0-1$ & $0-1$ & $|-1 ;|-1 ; \mid I, I, 5$ & $0-3 ; 1,2,2$ \\
\hline
\end{tabular}




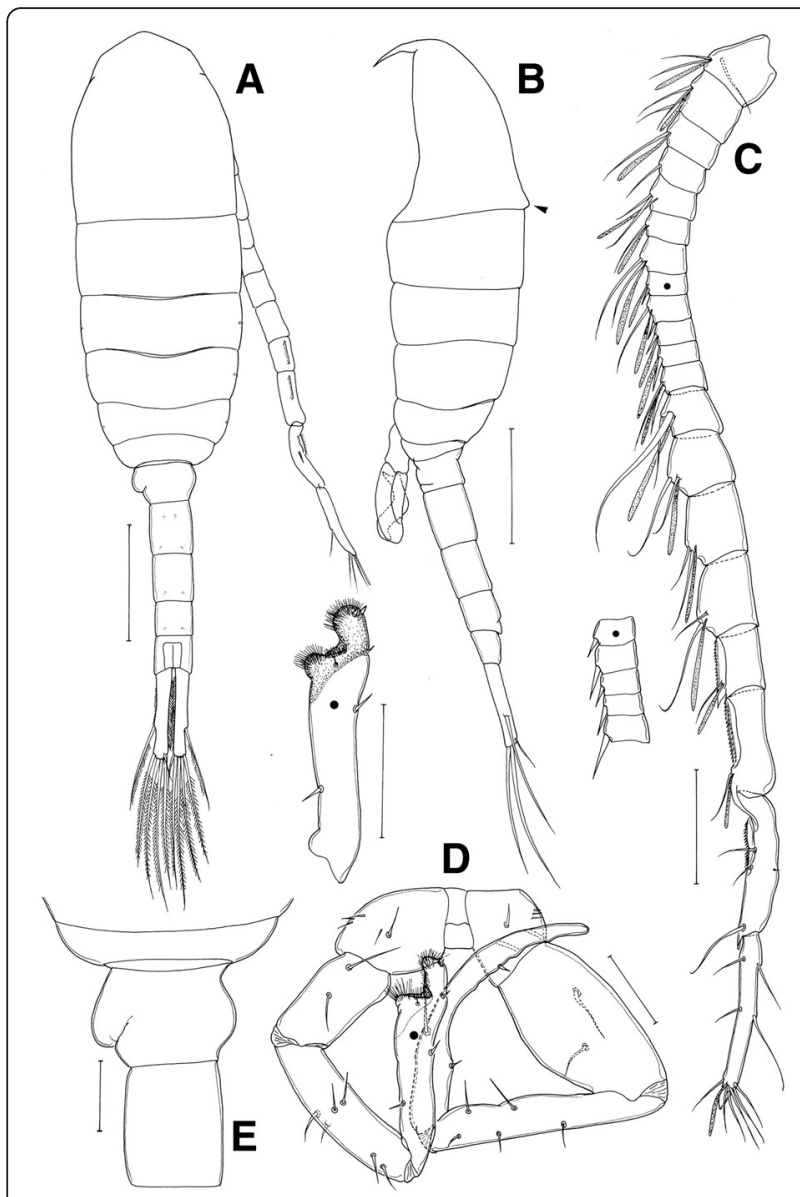

Fig. 5 Eurytemora americana, male: a habitus, dorsal view; b habitus, lateral view; c antennule (dot indicates the place of ancestral segments X to XIV); $\mathbf{d}$ P5 (dot indicates the place of distal segment of left leg 5), posterior view; e first and second urosomites, dorsal view. Scale bars: $A, B=200 \mu \mathrm{m} ; C=100 \mu \mathrm{m} ; \mathrm{D}, \mathrm{E}=50 \mu \mathrm{m}$

I-II-3 + ae, III-IV-3 + ae, V-1 + as, VI-1, VII-2 + ae, VIII-1 + ae, XI-2 + ae, X-I + ae, XI-2 + ae; XII-I + ae, XIII-I + ae, XIV-I-1 + ae, XV-2 + ae, XVI-2 + ae, XVII-2 + ae, XVIII-2 + ae, XIX-1 + ae, XX-1 + ae, XXI-XXIII-3, XXIV-XXVIII-1 +1-1+1-6+ ae. Segments XIX to XXI-XXIII supplied by comb-like structures/serrated.

All appendages as in female, except for fifth leg. Fifth leg strongly asymmetrical (Fig. 5d): Right leg 4segmented: coxa with two small setae on dorsal surface; basis with swelling on the inner margin, with lateral seta and 2 setae on dorsal surface; exopod 2segmented, proximal segment with 5 setae; distal segment falcate, inner margin irregular, with 2 min setae and lobe on proximal margin, 1 spine on medial margin, small seta on inner margin of distal half. Left leg 4-segmented: coxa with 2 setae and row of spinules on anterior surface; basis slightly swollen on inner margin with 2 setae on the dorsal surface; exopod 2- segmented, proximal segment with 4 setae on the medial surface and 2 setae on the distolaterally; distal segment with 1 proximal seta, 1 spine on mediolateral margin, apical portion of distal segment double broad ended, outer part extended to a swollen and rounded tipwith 1 long and 2 small spines; inner portion with cuticle crenate, anterior side with patch of thickly set fine hairs, protruding beyond margin.

\section{Distribution}

Species is widely distributed in the North America (Williams 1906; Heron 1964), northern Europe (Gurney 1933; Brylinski 2009), Argentina (Hoffmeyer et al. 2000) and Asia (Kos 1977; Borutzky et al. 1991).

\section{Discussion}

The original description of E. americana was brief with inadequate figures for the identification (Williams 1906). Some morphological features, that remain overlooked or undescribed still (Williams 1906; Willey 1923; Gurney 1933; Heron 1964; Kos 1977; Brylinski 2009) are redescribed in details in the present study for the both sexes of E. americana.

The following characters are proposed as diagnostic for female: (1) a symmetrical, lateral margins slightly constricted at midlength of the genital double-somite and (2) presence of patched spinules on the dorsal surface of the anal somite and caudal rami; and for the male: (1) a swelling on the inner margin of the right P5 basis; (2) the right distal segment of left P5 with falcate and double broad-ended apical portion; (3) presence of two setae on the dorsal surface of the coxa in right P5; (4) presence of two setae on the basis of right P5; (5) presence of five setae on the first exopodal segment of male right $\mathrm{P} 5$; (6) presence of two setae on the basis of left P5; and (7) presence of six setae on the first exopodal segment of left P5. The specimens herein identified as $E$. americana correspond well to the description of Heron (1964) and their undescribed mouth parts are illustrated in details for the first time.

Eurytemora americana usually co-occur with the other neritic calanoids, Acartia omorii Bradford, 1976, Centropages abdominalis Sato, 1913, E. pacifica, and Paracalanus intermedius Shen and Bay, 1956 as it was revealed during the biodiversity survey aimed at populating a distributional database on copepods in the eastern estuarine and shallow waters of Korea. A dense population of E. americana have been found in the estuary of Jeoncheon Stream, near by the Donghae harbor in the eastern Korea (salinity 25 psu, 5 May 2011).

Eurytemora americana has so far been known as a species widely distributed in the northern hemisphere, in the cold and temperate latitudes of North America (Williams 1906; Heron 1964), northern Europe (Gurney 


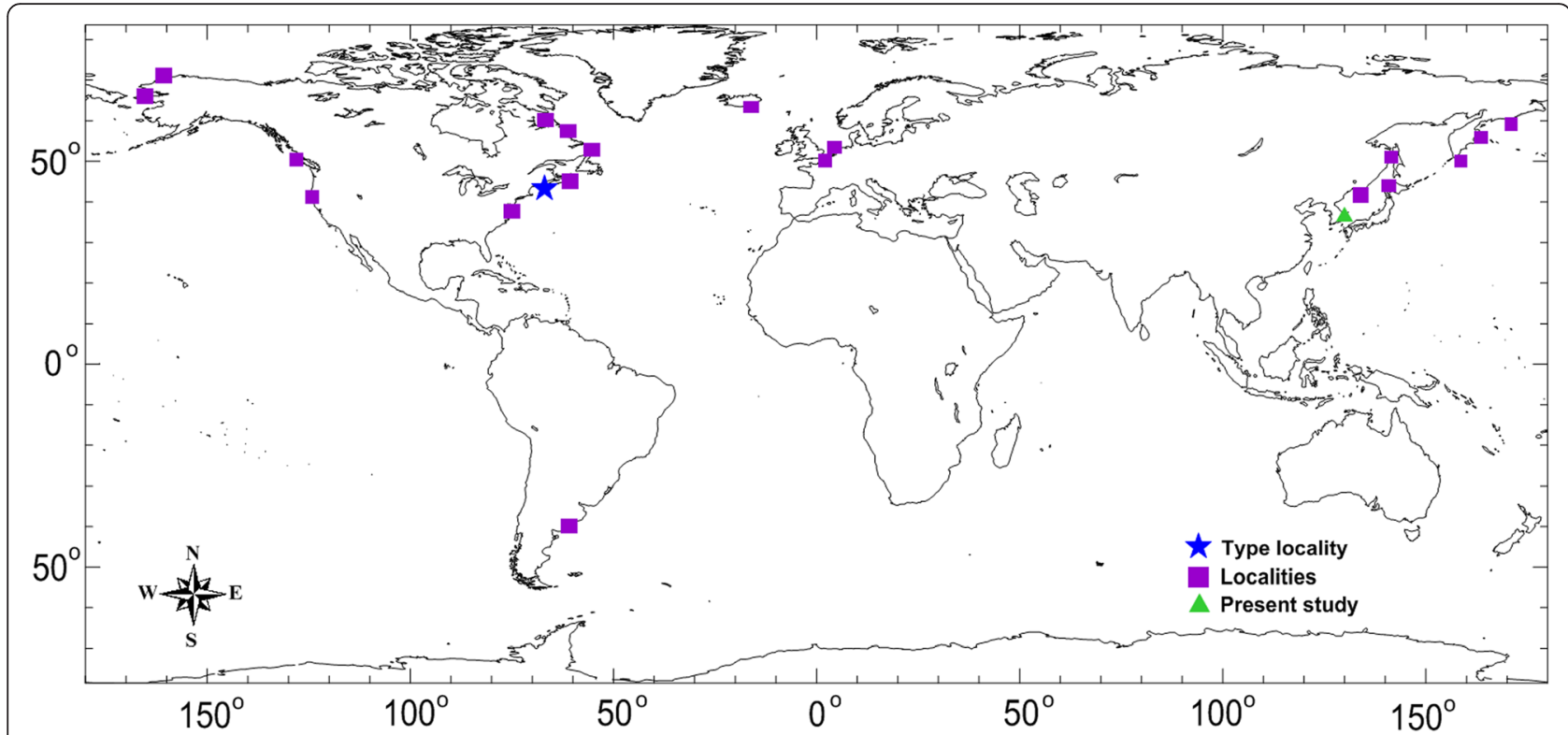

Fig. 6 Schematic illustration of latitudinal distributions of Eurytemora americana

1933; Brylinski 2009), the northeast Pacific (Kos 1977; Borutzky et al. 1991), and of Argentina (Hoffmeyer et al. 2000) in the southern hemisphere. This record extends to the known latitudinal distribution of this species southward into the temperate zone of the northern Korea $\left(37^{\circ} 39^{\prime} \mathrm{N}\right)$, which was the previous southern border of its known distributional range (see Fig. 6). This species is a brackish copepod native to the northern hemisphere (Kos 1977), but was accidentally introduced into the Argentina estuary with ballast water of ships coming to the harbour zone from the northern hemisphere locations (Hoffmeyer et al. 2000) and ultimately contributed to the establishment of invasion corridors (Ricciardi and MacIssac 2000; Drake and Lodge 2004). This species also has been reported several times as an invader species in Europe (Brylinski 2009; Noël 2011) through the ballast water (Brylinski 2009; Berasategui et al. 2009).

We report this particular species from the estuarine and coastal waters in the northern part of Korea for the first time. There are three possible explanations of this discovery: (1) insufficient studies of the northern Korean estuaries; (2) probable misidentification in previous studies; and (3) recent invasion of the species in the northern Korean waters. Since, it is a first record of occurrence in northern Korean waters, a detailed knowledge on its taxonomy and molecular variability imperative.

\section{Conclusions}

The present paper described for the complementary redescription of E. americana based on adult specimens collected from the estuarine and coastal waters of eastern Korea. When compared with descriptions and illustrations of earlier authors, they overlooked the shape of the last pedigerous somite in female, structure of the genital double-somite, and ornamentation of the fifth leg in both sexes. The expansion of the geographical distribution of E. americana is now given with its northern and southern hemisphere limit as 70 to $37^{\circ} \mathrm{N}$ in the North Pacific and $38^{\circ} \mathrm{S}$ in the Southwest Atlantic.

\section{Acknowledgment}

The authors extend their appreciation to Ms. Jung-Ah Lee for her great help in capturing the present specimens.

\section{Funding}

This work was supported by a grant from the National Institute of Fisheries Science (R2016033)

\section{Authors' contributions}

SYM collected the specimens, initially identified it, and drafted the manuscript and review and rewriting the manuscript drafts following editors' revisions. JHC, JUK and SKL wrote the manuscript together. BAVM participated in the drafting of the manuscript and processed the illustations. All authors have read and approved the final version of the manuscript.

\section{Competing interests}

The authors declare that they have no competing interests.

\section{Author details}

${ }^{1}$ Southeast Sea Fisheries Research Institute, National Institute of Fisheries Science, Tongyoung 53085, Korea. ${ }^{2}$ West Sea Fisheries Research Institute, National Institute of Fisheries Science, Incheon 22383, Korea. ${ }^{3}$ Institute for Phylogenomics and Evolution, Kyungpook National University, Daegu 41566, Korea.

Received: 23 July 2016 Accepted: 25 July 2016

Published online: 15 August 2016 


\section{References}

Alekseev V, Souissi A. A new species within the Eurytemora affinis complex (Copepoda: Calanoida) from the Atlantic Coast of USA, with observations on eight morphologically different European populations. Zootaxa. 2011;2767:41-56.

Berasategui AA, Hoffmeyer MS, Biancalana F, Fernandez SM. Menendez MC). Temporal variation in abundance and fecundity of the invading copepod Eurytemora americana in Bahía Blanca Estuary during an unusual year. Estuar Coast Shelf Sci. 2009:85:82-8.

Borutzky EV, Stepanova LA, Kos MS. Opredelitel' Calanoida presnykh vod SSSR [A Handbook of Calanida from the Freshwaters of the USSR]. Nauka Publishers, Leningard Opredeliteli po faune SSSR, izdavaemye Zoologicheskim insititutom An SSSR. 1991;156:1-503 [In Russian].

Boxshall GA, Halsey SH. An Introduction to Copepod Diversity, Part II. London: The Ray Society; 2004

Brylinski J-M. The pelagic copepods in the strait of Dover (Eastern English Channel). A commented inventory 120 years after Eugène Canu. Cah Biol Mar. 2009;50:251-60.

Dodson SI, Skelly DA, Lee CE. Out of Alaska: morphological diversity within the genus Eurytemora from its ancestral Alaskan range (Crustacea, Copepoda). Hydrobiologia. 2010;653:131-48.

Drake JM, Lodge DM. Global hotspots of biological invasions: evaluating options for ballast-water management. Proc R Soc Lond B. 2004;271:575-80.

Gurney R. British Fresh-water Copepoda. London: The Ray Society; 1933.

Heron GA. Seven species of Eurytemora (Copepoda) from northwestern North America. Crustaceana. 1964;7:199-211.

Heron GA, Damkaer DM. Eurytemora richingsi, a new species of deep-water calanoid copepod from Arctic ocean. Proc Biol Soc Wash. 1976;89:127-36.

Hoffmeyer MS, Frost BW, Castro MB. Eurytemora americana Williams, 1906, not Eurytemora affinis (Poppe, 1880), inhabits the Bahía Blanca estuary, Argentina. Sci Mar. 2000;64:111-3.

Humes AG, Gooding RU. A method for studying the external anatomy of copepods. Crustaceana. 1964;6:238-40.

Huys R, Boxshall GA. Copepod Evolution. London: The Ray Society; 1991.

Kos MS. Species of the genus Eurytemora (Copepoda, Calanoida) in northern part of the Pacific Ocean: systematics, distribution, variability. Issled Fauny Morei. 1977;20:20-53.

Lee CE. Global phylogeography of a cryptic copepod species complex and reproductive isolation between genetically proximate "populations". Evolution. 2000:54:2014-27.

Lee JM, Yoon HJ, Chang CY. A faunistic study on the brackish-water calanoid copepods from South Korea. Korean J Syst Zool. 2007;23:135-54.

Moon SY, Yoon HS, Soh HY, Choi SD. Environmental factors and variation characteristics of zooplankton communities in Gamak Bay. Ocean Polar Res. 2006;:8:79-94

Moon SY, Seo MH, Shin YS, Soh HY. Seasonal variation of mesozooplankton communities in the semi-enclosed Muan Bay, Korea. Ocean Polar Res. 2012;34:1-18.

Noël P. Checklist of cryptogenic and alien crustacea of the European Atlantic coast. In: Galil BS, Clark PF, Carlton JT, editors. In the wrong place-Alien marine crustaceans: distribution, biology and impacts. Springer: Berlin; 2011. p. $345-75$.

Park C, Lee PG, Yang SR. Variation of zooplankton distribution in the Seomjin River estuary with respect to season and salinity gradients. J Korean Soc Oceanogr. 2002;7:51-9.

Ricciardi A, Macisaac HJ. Recent mass invasion of the north American Great Lakes by Ponto-Caspian species. Trands Ecol Evol. 2000;15:62-5.

Soh HY. Invertebrate fauna of Korea, vol. 21, no. 3, Marine Planktonic Copepods. Flora and Fauna of Korea Series. National Institute of Biological Resources, GB; 2010

Soh HY, Moon SY, Wi JH. Invertebrate fauna of Korea, 21(27), Marine Planktonic Copepods. Flora and Fauna of Korea Series. National Institute of Biological Resources, GB; 2013.

Sukhikh NM, Alekseev VR. Eurytemora caspica sp. nov. from the Caspian Sea-one more new species within the E. affinis complex (Copepoda: Calanoida: Temoridae). Proc Zool Inst Russ Acad Sci. 2013;317:85-100

Willey A. Notes on the distribution of free-living Copepoda in Canadian waters. Contrib Can Biol Fish. 1923;1:303-334.

Williams LW. Notes on marine Copepoda of Rhode Island. Am Nat. 1906;40: $639-660$

\section{Submit your next manuscript to BioMed Central and we will help you at every step:}

- We accept pre-submission inquiries

- Our selector tool helps you to find the most relevant journal

- We provide round the clock customer support

- Convenient online submission

- Thorough peer review

- Inclusion in PubMed and all major indexing services

- Maximum visibility for your research

Submit your manuscript at www.biomedcentral.com/submit

) Biomed Central 